Japan. J. Med. Sci. Biol., 39, 49-66, 1986.

\title{
ULTRASTRUCTURAL STUDIES ON THE EFFECT OF TRITON WR-1339 ON MACROPHAGE-MYCOBACTERIA INTERACTION
}

\author{
Eiko KONDO, Kenji SUZUKI1 and Koomi KANAI \\ Department of Cellular Immunology and 1Laboratory of Technology, National \\ Institute of Health, Kamiosaki, Shinagawa-ku, Tokyo 141
}

(Received March 12, 1986. Accepted May 28, 1986)

SUMMARY: Mycobacterium bovis (BCG organisms) suspended in saline or a 5\% solution of a non-ionic detergent, Triton WR-1339, was injected intraperitoneally into mice. Electron-microscopic observation was carried out on peritoneal exudate cells harvested therefrom. Electron-lucent vacuoles limited by the membrane structure were found in macrophages of the mice injected with BCG suspended in the detergent, but not in polymorphonuclear leukocytes or lymphocytes. Mycobacterial cells were present within such vacuoles. Without the detergent, the ingested mycobacterial cells were in close contact with the phagosomal membrane. Within the electron-lucent vacuoles, however, such close contact was not present. These observations, together with other collateral findings, led us to a view that Triton WR-1339 may inhibit the interaction between mycobacteria and the phagosomal membrane by intervening between them thus making the progress of infection delayed.

\section{INTRODUCTION}

In the preceding paper (1), we reported that Triton WR-1339 (oxyethylated tert. octyl phenol polymer) modified the course of experimental mouse tuberculosis prolonging their survival time. Though this non-ionic detergent is known to lack the direct antimycobacterial activity, our study showed that it has such a unique property as a membrane-active agent. Therefore, we were tempted to consider that the antituberculous effect of Triton WR-1339 is interpreted from a broader biological concept, especially at the level of biomembrane.

\footnotetext{
近藤犖子(国立予防衛生研究所細胞免疫部)

鈴木健之(国立予防衛生研究所技術部)

金井興美(国立予防衛生研究所)
} 
On the other hand, Myrvik et al. (2), Leake et al. (3), and ourselves (4) have pointed out that the crucial event in the intracellular infection with mycobacteria may be the direct interaction between the phagosomal membrane and the ingested bacterial cells. We predicted that Triton WR-1339 will modify the mode of intracellular parasitism by interfering with such membrane-bacteria association within phagocytes. The present paper is to present our ultrastructural observations in an attempt to examine the above prediction.

\section{MATERIALS AND METHODS}

Electron-microscopic observation: Fifty male mice of ddY strain weighing around $30 \mathrm{~g}$ were divided into two groups of equal half. The animals of one group were each injected intraperitoneally with $2 \mathrm{ml}$ of a $10 \mathrm{mg}$ per $\mathrm{ml}$ saline suspension of BCG. Those of the other group were injected in the same way excepting that the saline contained Triton WR-1339 in $5 \%$.

In respect to each group, 10 mice in $15 \mathrm{hr}$ and the remaining 15 mice in 4 days were sacrificed to harvest the peritoneal exudate cells. The peritoneal cavity was lavaged with chilled Hanks' solution containing heparine in 5 units per ml. The lavage fluid was pooled and let pass through a stainless steel sieve of 100 mesh. The peritoneal cells were collected and washed with Hanks' solution by centrifugation of the filtrate. The cells were used to prepare specimens for electron-microscopic observation. The procedure of specimen preparation was that of Hirsch and Fedorko (5) with some modification. The cells were placed in a polyethylene capsule of 1-ml capacity to be immersed in a 1:1 mixture of a glutaraldehyde $(5 \%)$ - paraformaldehyde $(4 \%)$ aqueous solution in $0.3 \mathrm{M}$ cacodylate buffer ( $\mathrm{pH}$ 7.4). This was left to stand in an ice bath for $90 \mathrm{~min}$. After centrifugation, the resulting cell pellet was fixed with a 1:1 mixture of a $2 \%$ aqueous solution of osmic acid and the cacodilate buffer at $4 \mathrm{C}$ for $3 \mathrm{hr}$. After replacing the fixative with fresh one, the post fixation was carried out for further $72 \mathrm{hr}$ at $4 \mathrm{C}$. The cell pellet washed by centrifugation with $0.15 \mathrm{M}$ cacodylate buffer was stained for $60 \mathrm{~min}$ with $0.5 \%$ uranyl acetate in $0.1 \mathrm{M}$ veronal buffer, $\mathrm{pH}$ 6.8. It was then dehydrated in graded ethanol and finally in $n$-butyl glycidyl ether (QY-1). The specimen was embedded into a mixture of low viscosity epoxy resins, ERL 4206 and Quetol 653, according to the method of Kushida (6). The formula was $23 \mathrm{ml}$ of ERL 4206, $14 \mathrm{ml}$ of Quetol 653 (Nissin EM Co., Tokyo), $63 \mathrm{ml}$ of nonenyl succinic anhydride (NSA), and $0.5 \mathrm{ml}$ of dimethylaminoethanol (S-1). Ultra-thin sections were cut on an LKB ultratome and stained with $2 \%$ uranyl acetate (7) followed by lead acetate ( 8 ). The sections were observed with a Hitachi $\mathrm{H}-500$ electron microscope at $75 \mathrm{kv}$.

Inhibitory effect of Triton WR -1339 on mycobacateria-induced liposomal lysis: Artificial biomembranes (liposomes) were employed to conduct an in vitro model 
experiment to see the effect of Triton WR-1339 on the interaction between mycobacteria and the biomembrane. Our concern was whether or not Triton WR1339 was capable of inhibiting liposomal lysis by mycobacteria as we reported previously (9).

A suspension of BCG organisms exposed to Triton WR-1339 was prepared in the following way: An aqueous suspension $(1.35 \mathrm{ml})$ of BCG $(20 \mathrm{mg} / \mathrm{ml})$ was combined with $0.15 \mathrm{ml}$ of a Triton WR-1339 solution $\left(10^{-3} \%\right)$ and shaken gently for a while. Then, the bacterial cells were collected and washed twice with PBS by centrifugation at 2,000 $\mathrm{rpm}$ for $10 \mathrm{~min}$. The final pellet was resuspended in PBS to the same turbidity (OD $420 \mathrm{~nm}$ ) as a $2 \mathrm{mg}$ per ml suspension of untreated (control) BCG. Heat-killed ( $100 \mathrm{C}, 10 \mathrm{~min}$ ) BCG was also employed for comparison.

On the other hand, the multilamellar lecithin-cholesterol liposomes entrapping carboxyfluorescence as a specific marker were prepared according to the method described previously (10). The liposome preparations were then dispensed into glass tubes of $12 \times 75 \mathrm{~mm}$ (Corning Glass Works, Corning, NY) in 5- $\mu 1$ amounts together with $50 \mu 1$ of veronal-buffered saline supplemented with gelatin to a final concentration of $0.1 \%$ (GVB). To these tubes, a suspension of BCG treated or not treated with Triton WR-1339 was added in 100- $\mu$ l amounts. The tubes were then shaken gently and left to stand at room temperature. After 1.5 and $3 \mathrm{hrs}$, the mixtures were sampled at random to be diluted with $2 \mathrm{ml}$ of PBS and subjected to the spectrofluorophotometric determination of percent marker release.

Inhibitory effect of Triton WR-1339 on melittin-stimulated mycobactericidal activity of the membrane fraction isolated from mouse peritoneal exudate cells: In a previous paper (11), we reported that the membrane fraction isolated from mouse peritoneal exudate cells were mycobactericidal, especially in the presence of added melittin which is a potent stimulator of membrane-bound phospholipase A activity. In this experimental system, we attempted the use of Triton WR-1339 presuming that it might act as an inhibitor of that event. The methods were the same as those described previously (11). The membrane fraction (MF) was prepared from mononuclear-predominant $(71 \%)$ cell population of normal mice. The incubation system consisted of $100 \mu \mathrm{l}$ of $0.05 \mathrm{M}$ acetate buffer ( $\mathrm{pH} 5.6$ ), $10 \mu \mathrm{l}$ of $100 \mathrm{mM} \mathrm{CaCl}_{2}, 100 \mu \mathrm{l}$ of a $1 \mathrm{mg} \mathrm{H} 37 \mathrm{Rv}$ tubercle bacilli per $\mathrm{ml}$ suspension, $100 \mathrm{ml}$ of MF, $10 \mu \mathrm{l}$ of a $250 \mu \mathrm{g}$ melittin (Sigma, St. Louis, MO) per ml solution, and with or without $10 \mu \mathrm{l}$ of $3 \%$ Triton WR-1339. Viable counts at 0,8 and $16 \mathrm{hrs}$ were determined as routinely (12) by sampling the tubes.

\section{RESULTS}

Mononuclear cell response to BCG in peritoneal exudate took the welldocumented pattern when examined with the specimens of Giemsa staining. In the cell harvest at $15 \mathrm{hr}$, polymorphonuclear leukocytes were predominant and 
mononuclear cells were only $1.2 \%$. In 4 days, the rate increased to $24 \%$. In the presence of Triton WR-1339, mononuclear cell response was accelerated, the rate being $25.2 \%$ in $15 \mathrm{hr}$ and $27.2 \%$ in 4 days (Table I)

Electron-microscopical observation showed that most of the mononuclear cells were macrophages and lymphocytes were around $10 \%$ of the mononuclears. The most unique finding in the general survey of ultra-thin sections was the frequent presence of electron-lucent vacuoles with diameters ranging from 1 to 3 $\mu \mathrm{m}$ within macrophages of Triton-injected animals. No such vacuoles were present in polymorphonuclear leukocytes or lymphocytes (Table II). Lipoidal inclusions were very similar to them in dimension and located in the same area. They were, however, more electron-dense and never contained bacterial bodies unlike the electron-lucent vacuoles (Figs. 1 and 2).

Figure 3 is a representative form of peritoneal macrophages from the animals injected with BCG alone. The cell is equipped with well-developed organella and a phagosome associated with two bacterial cells is seen in this section. The region of the phagosome is enlarged in Fig. 4, in which the morphological relation between the bacterial surface and the phagosomal membrane is plainly revealed. The outmost layer of the upper bacterial cell (arrow) appears to be an integral part of the cell wall at a glance. However, the layer is evidently the continuation of the major part of the phagosomal wall. In other words, the contact between the bacterial surface and the phagosomal membrane is so tight that the latter looks

Table I. Mononuclear cell response to BCG in peritoneal exudate as enhanced and accelerated by Triton WR-1339

\begin{tabular}{lrrrr}
\hline \multirow{2}{*}{$\begin{array}{l}\text { Ip injection of BCG } \\
\text { suspended in }\end{array}$} & \multicolumn{4}{c}{$\begin{array}{c}\text { \% cell distribution in the peritoneal } \\
\text { exudate harvested in } \\
\text { 15 days }\end{array}$} \\
\cline { 2 - 6 } & $\mathrm{P}$ & $\mathrm{M}$ & $\mathrm{P}$ & $\mathrm{M}$ \\
\hline Saline & 98.8 & 1.2 & 76.4 & 23.6 \\
Triton WR-1339 & 74.8 & 25.2 & 72.8 & 27.2 \\
\hline
\end{tabular}

P: Polymorphonuclear leukocytes.

M: Mononuclear cells. 
like the outmost layer of the bacterial cell wall. The lower bacterial cell looks the same, but the adhering membrane may be in degradation here as to making the bacterium release into the cytoplasm.

Figure 5 (macrophage) and Fig. 6 (polymorphonuclear leukocytes) show that such close contact is a phenomenon very common to intracellular mycobacteria regardless of the kind of the host phagocyte. Every bacterial cell has the same ultrastructural feature as we noticed in Fig. 4. So far as the bacterial cells we surveyed were concerned, 41 within polymorphonuclear leukocytes and 53 within macrophages, all of them were encapsulated tightly with the phagosomal membrane.

On the other hand, the morphological situation in macrophages obtained from the animals injected with BCG plus Triton WR-1339 was quite different in this respect (Figs. 7 and 8). Figure 7 is a macrophage from such an animal. Its cytoplasma is loaded with many electron-lucent vacuoles limited by the membraneous structure and also with moderately dense granules of similar sizes.

Table II. Intracellular presence of electron-lucent vacuoles in peritoneal exudate cells induced by BCG cells suspended in Triton WR-1339

\begin{tabular}{|c|c|c|c|}
\hline \multirow{2}{*}{$\begin{array}{l}\text { Induced by } \\
\text { BCG cells } \\
\text { suspended in }\end{array}$} & \multirow{2}{*}{$\begin{array}{l}\text { Peritoneal } \\
\text { cells }\end{array}$} & \multicolumn{2}{|c|}{$\begin{array}{l}\text { Number of peritoneal cells in which } \\
\text { electron-lucent vacuoles are }\end{array}$} \\
\hline & & Observed & Not observed \\
\hline \multirow{3}{*}{$\begin{array}{l}\text { Triton } \\
\text { WR-1339 }\end{array}$} & Macrophages & 15 & 2 \\
\hline & $\begin{array}{l}\text { Polymorpho- } \\
\text { nuclear leuko- } \\
\text { cytes }\end{array}$ & 0 & 19 \\
\hline & Lymphocytes & 0 & 4 \\
\hline \multirow{3}{*}{$\begin{array}{l}\text { Saline } \\
\text { control }\end{array}$} & Macrophages & 0 & 5 \\
\hline & $\begin{array}{l}\text { Polymorpho- } \\
\text { nuclear leuko- } \\
\text { cytes }\end{array}$ & 0 & 4 \\
\hline & Lymphocytes & 0 & 2 \\
\hline
\end{tabular}


The latters are lipoidal droplets in their appearance. Four bacterial cells are seen within the largest electron-lucent vacuole in the upper left area. This area is enlarged in Fig. 8. The bacteria appear as if floating within this round vacuole contacting only slightly to the inner surface, but never being encapsulated by the limitting membrane. Even in the contacting site, the bacterial surface is distinct from the vacuolar membrane showing a very narrow interspace between them. In Fig. 9 (macrophage), such morphological features are demonstrated more clearly around a longitudinally cut bacterial cell. The vacuolar membrane is never in close contact with the bacterial cell ingested therein. The difference is so evident between Figs. 5 and 9 in this respect. Figure 10 is a polymorphonuclear leukocyte obtained from the animal group of Triton-injection. Ten transversally cut bacterial cells are enclosed with a single membrane strucrture. Unlike the case of macrophage, the electron-lucent space is not evident. However, the morphological

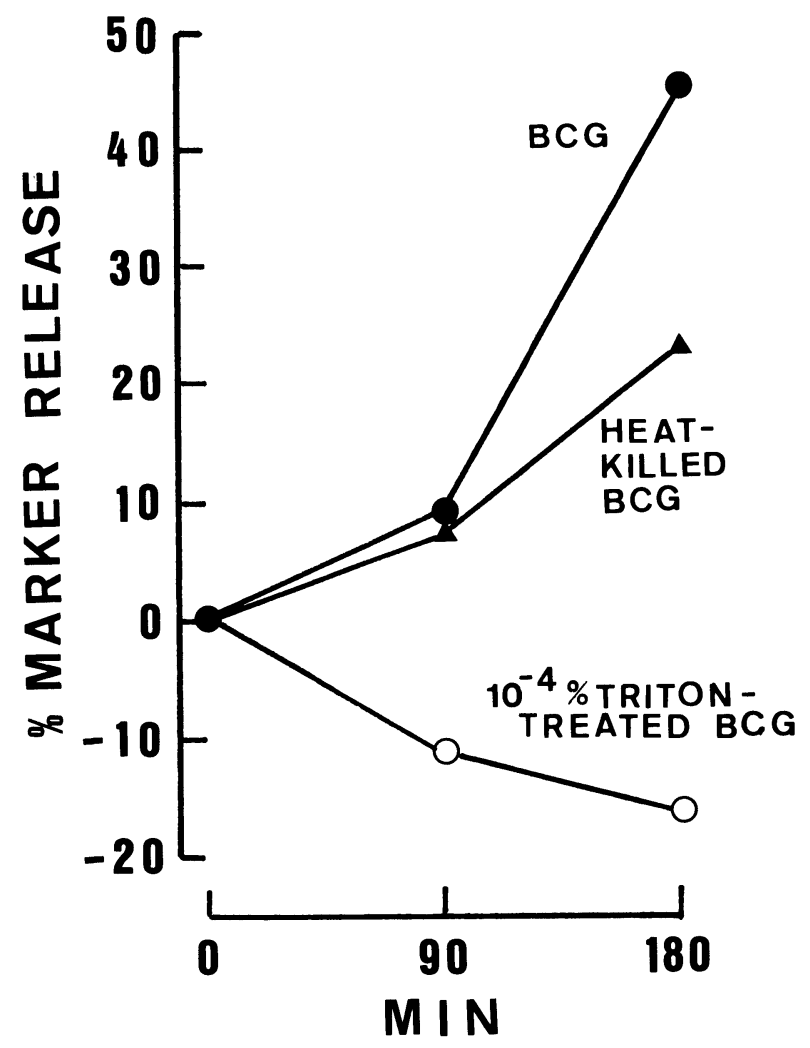

Fig. 13. Inhibition by treatment with Triton WR-1339 of liposome-lytic effects of BCG. 
relation between the bacterial surface and the membrane is not the same as that we see in Fig. 6. They are very near each other, but never in close contact. It may be that, though polymorophonuclear leukocytes do not pinocytose Triton WR-1339, those mycobacteria are thinly coated with the detergent. In the lower corner, we can see a bacterial cell (arrow) which is so vague losing the well-defined cell wall and cytoplasmic features. It is encircled with an electron-dense material which is supposed to consist of a degradation product of the membrane, possibly together with some material discharged from lysosomes. Such degradation form of ingested bacteria is often seen in the animal group of BCG injection without Triton (arrows in Figs. 11 and 12).

In view of the observations stated above, our assumption was that Triton WR1339 may play a role in inhibition of the close contact between the phagosomal membrane and the ingested mycobacteria. This idea led us to an attempt to examine whether or not Triton WR-1339 can inhibit the liposomal lysis by mycobacteria (BCG) in the incubation system described before (9). As shown in

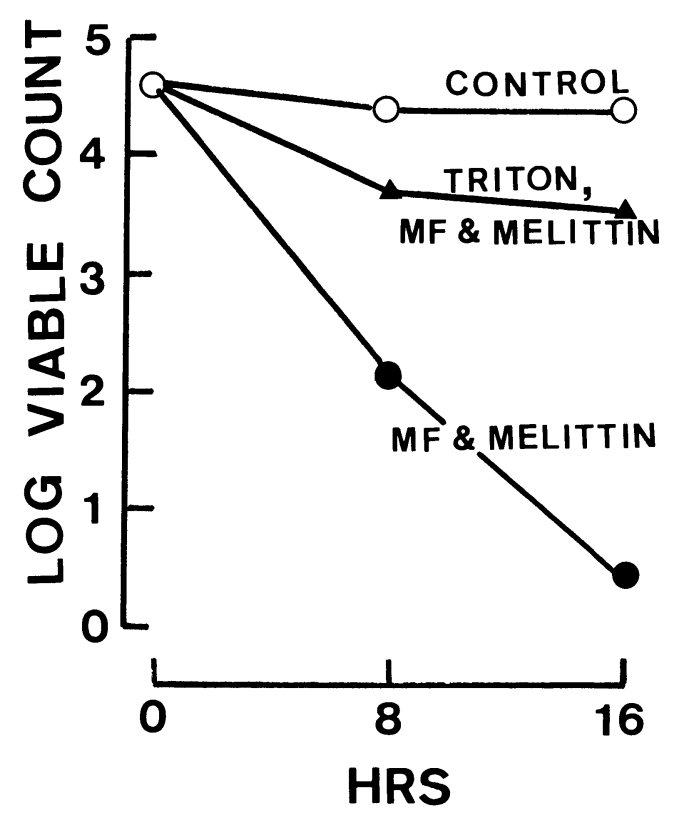

Fig. 14. Inhibition by Triton WR-1339 of melittin-stimulated bactericidal effects of the membrane fraction (MF). 
Fig. 13, the effect of $10^{-4} \%$ Triton WR-1339 was clear-cut and even more remarkable than the killing by heat in reducing the liposomal lytic activity of BCG.

We have already reported that the membrane fraction (MF) isolated from mouse phagocytes can kill mycobacteria in a mixed incubation system, especially in the presence of melittin added, a membrane-active agent which is known as a stimulator of endogenous phospholipase A (11). In this context, we examined the effect of Triton WR-1339 on the antimycobacterial activity of MF in such a system. 'The result is shown in Fig. 14. In the presence of MF and melittin, viable count in the incubation system decreased down to less than one-hundredth of the original in $8 \mathrm{hr}$ and then to one-ten thousandth in $16 \mathrm{hr}$. In the presence of Triton WR-1339, however, the level of viable counts remained at one-tenth of that at 0 time during this period.

\section{DISCUSSION}

This study was undertaken as an extension of the previous finding (1) that a non-ionic detergent, Triton WR-1339, modified the course of experimental mouse tuberculous infection as to prolong their survival time. Though such a protective mechanism is suggested to be associated with macrophages (13), the action of Triton WR-1339 within the cell still remains as a matter of speculation. Our academic interest in this detergent was renewed during the progress of our study which suggests that the close contact between the phagosomal membrane and ingested mycobacteria is an important facet at a later stage of intracellular infection $(4,11,14)$. Our prediction was that Triton WR-1339 will interfer with the close contact when it is ingested by macrophages together with mycobacteria. The prediction was examined by ultrastructural study with an electron microscope.

It was a remarkable finding that many electron-lucent round vacuoles of 1 to $3 \mu \mathrm{m}$ in diameter were present only in macrophages obtained from the mice injected with the detergent. The vacuoles were limited by the membrane structure. A very similar observation was reported by Armstrong and Hart (15) in the macrophages maintained in tissue-culture environment containing the same kind of detergent, Macrocyclon, a antituberculous agent (one of the polyethylene glycol ethers having a mean mol wt of about 3,100). From these circumstantial evidences, there is a good reason to believe that electron-lucent vacuoles are the Triton-containing phagosomes. The vacuoles were often loaded with mycobacterial cells. However, the ingested bacterial cells were never encapsulated 
tightly as used to be so in the usual phagosome without Triton WR-1339. In support of our prediction, the outmost layer of the bacterial cell was separated from the phagosomal membrane possibly by intervention of the detergent between the two.

Though Triton WR-1339 is not lytic to the biomembrane, it appears to have a capacity to act substantially with it $(1,16)$. On the other hand, the detergent has a strong affinity to the hydrophobic surface of mycobacteria making them hydrophilic; thus the dispersing cultivation is possible in the liquid medium (17). 'Therefore, it is quite natural to think that Triton WR-1339 may inhibit the hydrophobic interaction between the lipid bilayer of the membrane and the mycobacterial surface. Our model experiment with liposomes supports the above idea. The close contact between the phagosomal membrane and the ingested mycobacteria results in damage of the membrane and subsequent release of intraphagosomal mycobacteria into the cytoplasm (3). In this context, Triton WR1339 may act as a membrane-protector at the time of intracellular infection. Because of this, it may be a biological response modifier to make the progress of infection delayed.

On the other hand, we suspect that the degradation products (free fatty acids and lysolecithines) of the phagosomal membrane at the site of close contact with mycobacteria may have a chance to act as antimycobacterial agents. Our model study with the membrane fraction isolated from phagocytes supported this idea with the finding that the stimulation of membrane phospholipase $A$ is involved in this event $(11,14)$. Therefore, the activator of this enzyme, such as melittin, enhanced the bactericidal activity of the fraction. In such an experimental system, Triton WR-1339 was found to inhibit the event.

\section{REFERENCES}

1. Kondo, E. and Kanai, K. (1986): Japan. J. Med. Sci. Biol., 39, 35-47.

2. Myrvik, Q. N., Leake, E. S. and Wright, M. J. (1984): Amer. Rev. Resp. Dis., 129, 322-328.

3. Leake, E. S., Myrvik, Q. N. and Wright, M. J. (1984): Infect. Immun., 45, 443446.

4. Kanai, K., Kondo, E. and Yasuda, T. (1981): Tubercle, 62, 187-195.

5. Hirsh, J. G. and Fedorko, M. E. (1968): J. Cell Biol., 38, 615-627.

6. Kushida, H. (1980): J. Electron Microscop., 29, 193-194.

7. Watson, M. L. (1958): J. Biophys. Biochem. Cytol., 4, 475-478. 
8. Venable, J. H. and Coggeshall, R. A. (1965): J. Cell Biol., 25, 407-408.

9. Kondo, E., Suzuki, K., Kanai, K. and Yasuda, T. (1985): Japan. J. Med. Sci. Biol., 38, 169-180.

10. Yasuda, T., Naito, Y., Tsumita, T. and Tadakuma, T. (1981): J. Immunol. Meth., 44, 153-158.

11. Kondo, E. and Kanai, K. (1986): Japan. J. Med. Sci. Biol., 39, 9-20.

12. Kanai, K. and Kondo, E. (1971): Japan. J. Med. Sci. Biol., 24, 313-321.

13. Machaness, G. B. (1954): Amer. Rev. Tuberc., 69, 690-704.

14. Kondo, E. and Kanai, K. (1985): Japan. J. Med. Sci. Biol., 38, 181-194.

15. Armstrong, J. A. and Hart, D. P. (1971): J. Exptl. Med., 134, 713-740.

16. Hart, D. P. (1968): Nature, 162, 686-689.

17. Hirsch, J. G. (1955): Amer. Rev. Tuberc., 71, 894-897. 
Figs. 1 and 2. The presence of many electon-lucent vacuoles within a macrophage in the cell population of the peritoneal exudate induced by BCG suspended in a Triton WR-1339 solution. In these figures, electonlucent vacuoles (ELV) are seen only in macrophages (MP) but not in polymorphonuclear leukocytes (PNL). Bacterial bodies are seen within some ELV, but not within moderately electron-dense lipoidal droplets (LD).

Fig. 3. A macrophage of the representative appearance in the peritoneal exudate induced by saline-suspended BCG. The cytoplasm is equipped with well-developed organella. A few bacterial cells are present within a phagosome (arrow).

Fig. 4. A higher magnification of the area indicated by arrow in Fig. 3. Two bactrial cells are within a phagosome being encapsulated tightly by the extended phagosomal membrane. The phagosome is filled with dispersed amorphous material of high electron-density. The membrane around the lower bacterial cell may be in degradation so that the bacterium is going to escape into the cytoplasm.

Fig. 5. Mycobacterial cells (BCG) located within the cytoplasm of macrophage. Each bacterial cell is encapsulated so tightly with the phagosomal membrane that it appears to be an integral part of the bacterial cell wall.

Fig. 6. Mycobacterial cells (BCG) located within the cytoplasm of polymorphonuclear leukocyte. The morphological situation is similar to Fig. 5. Some of them are associated with highly electron-dense material (granule). Arrow indicates the extension of the limitting membrane of a dense granule to encapsulate a bacterial cell.

Fig. 7. A macrophage of the representative appearance in the peritoneal exudate induced by BCG suspended in Triton-containing saline. The cytoplasm has many electron-lucent vacuoles of 1 to $3 \mu \mathrm{m}$ in diameter. In some of the vacuoles 3 to 4 bacterial cells are seen. 
Fig. 8. The electron-lucent vacuole indicated by an arrow in Fig. 7 is shown in a higher magnification. The bacterial cells within the electronlucent vacuole are not encapsulated by the membrane but appear touching slightly with it. The close contact as we see in Figs. 5 and 6 is not seen here.

Fig. 9. A longitudinal section of BCG within an electron-lucent vacuole. The outmost layer of cell wall is distinct from the limitting membrane of the vacuole in marked contrast to be the feature of the close contact in Fig. 4.

Fig. 10. A group of BCG organisms encapsulated by the phagosomal membrane in a polymorphonuclear leukocyte (PNL) which is from the animal group of BCG-Triton. Around the bacterial surface there is no space to be called electron-lucent vacuole. However, the outmost layer of the bacterial cell wall is still distinct from the phagosomal membrane. The bacterium indicated by an arrow is possibly in the stage of degeneration together with the membrane around it.

Figs. 11 and 12. Degenerative forms (arrow) possibly developed from the bacteria encapsulated tightly with the phagosomal membrane in macrophages. The macrophages are from the animal group injected with the saline suspension of BCG. 

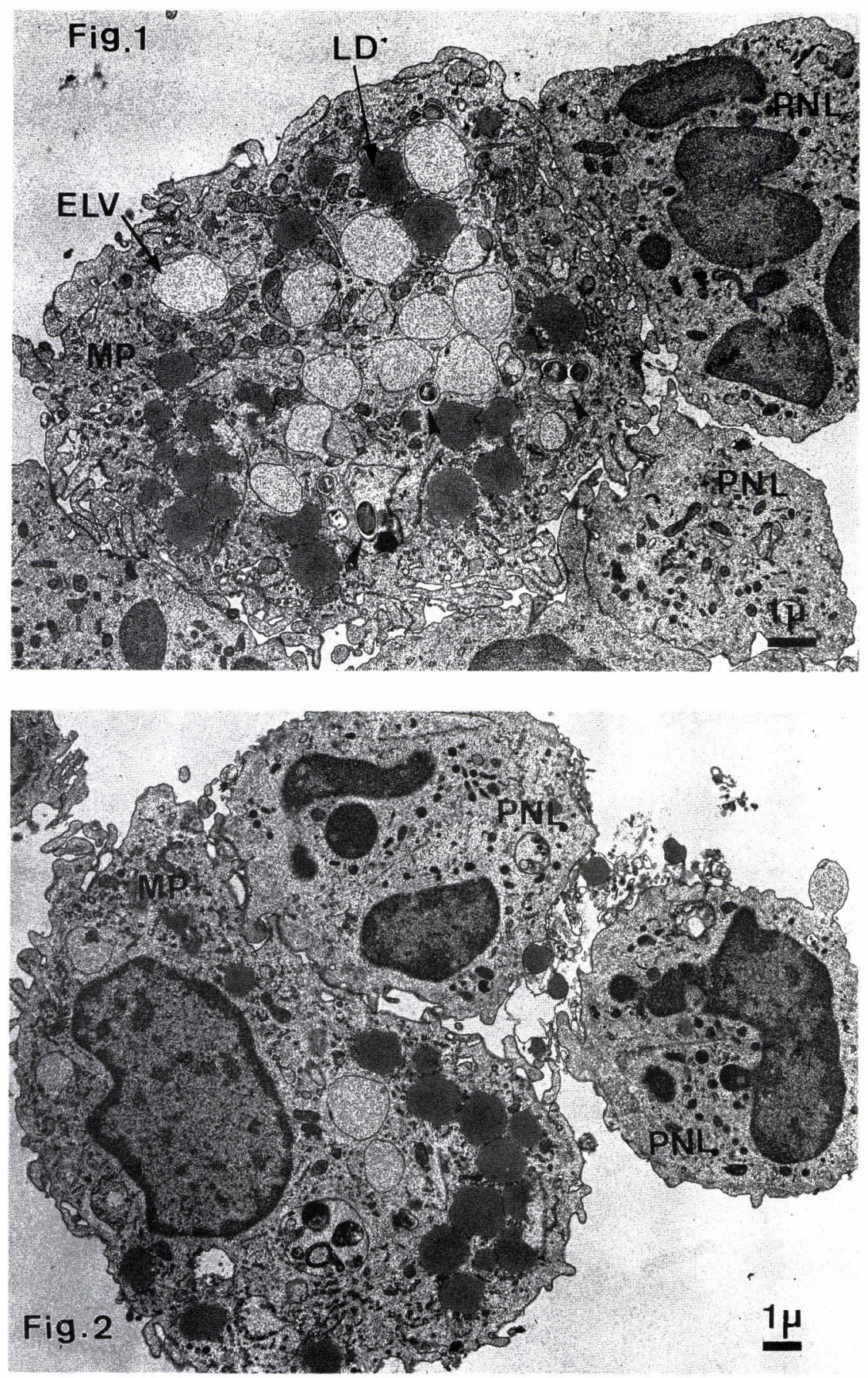

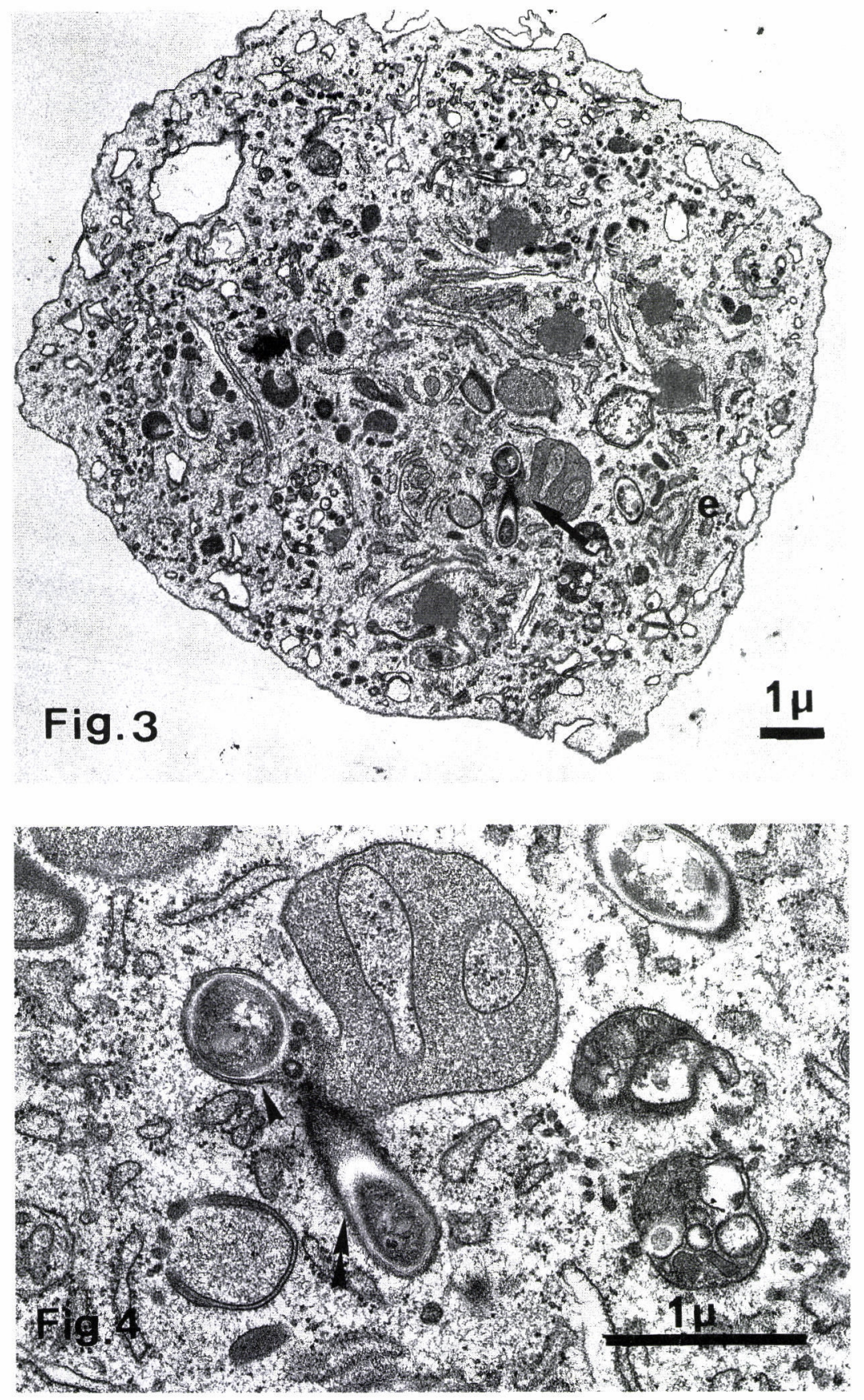

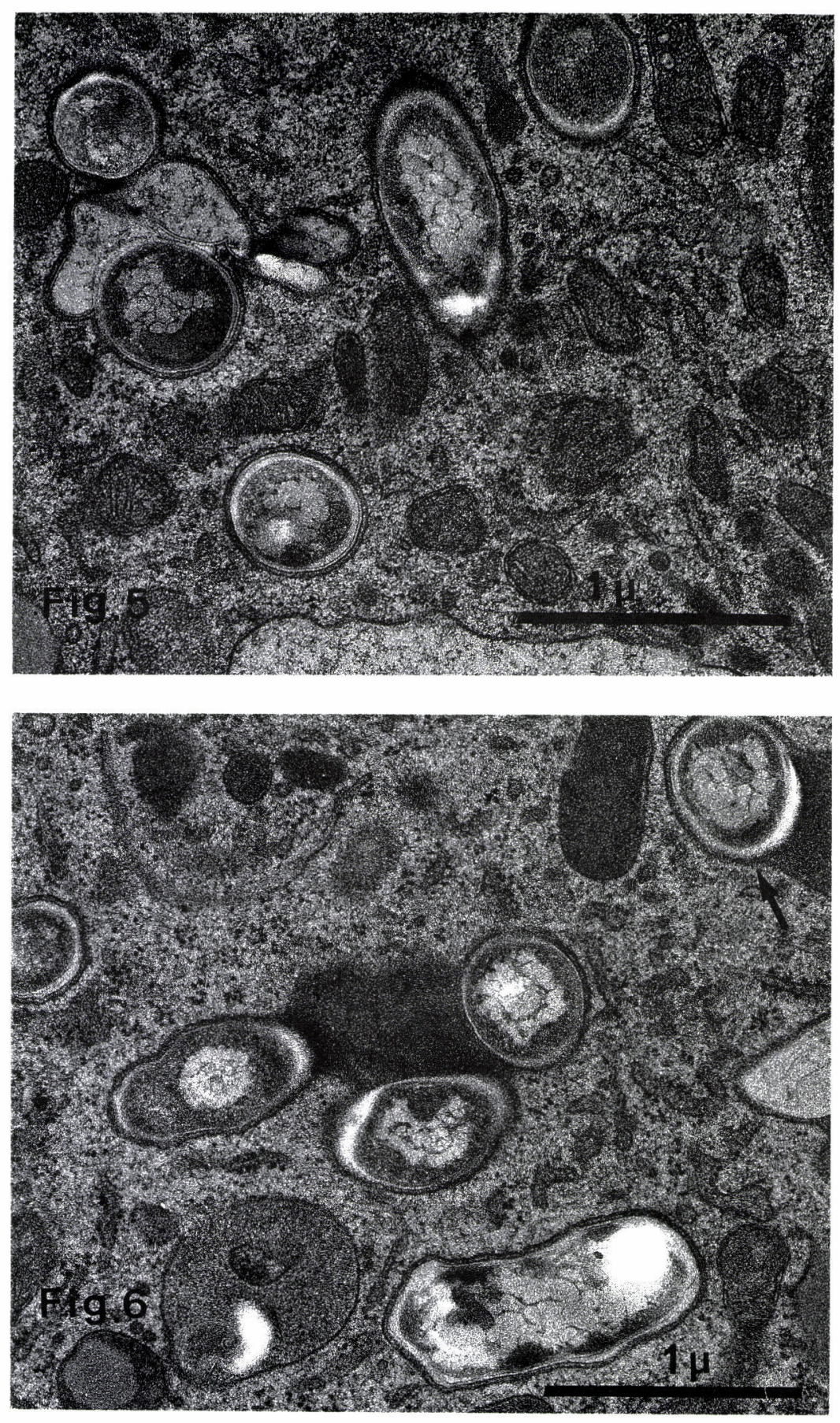

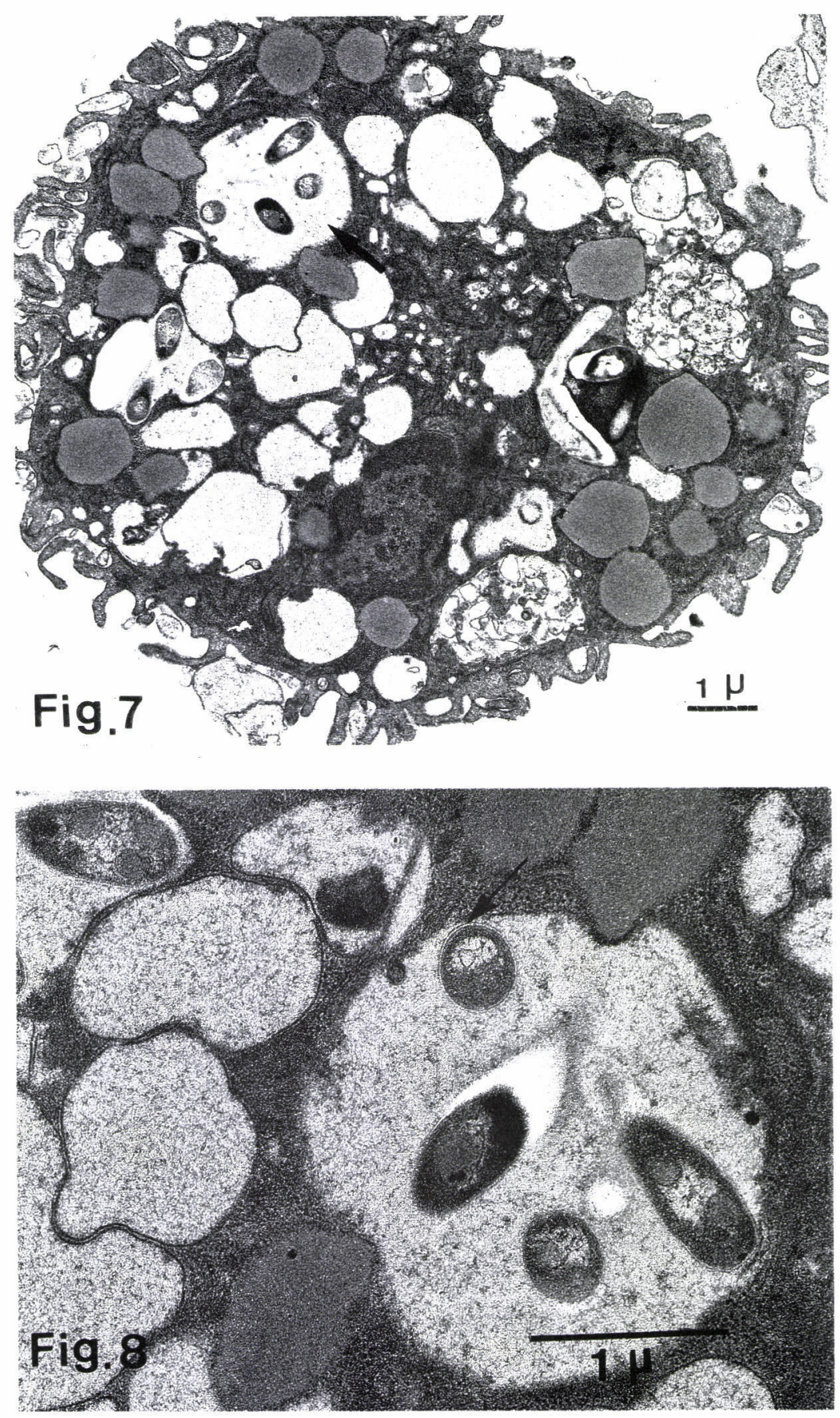

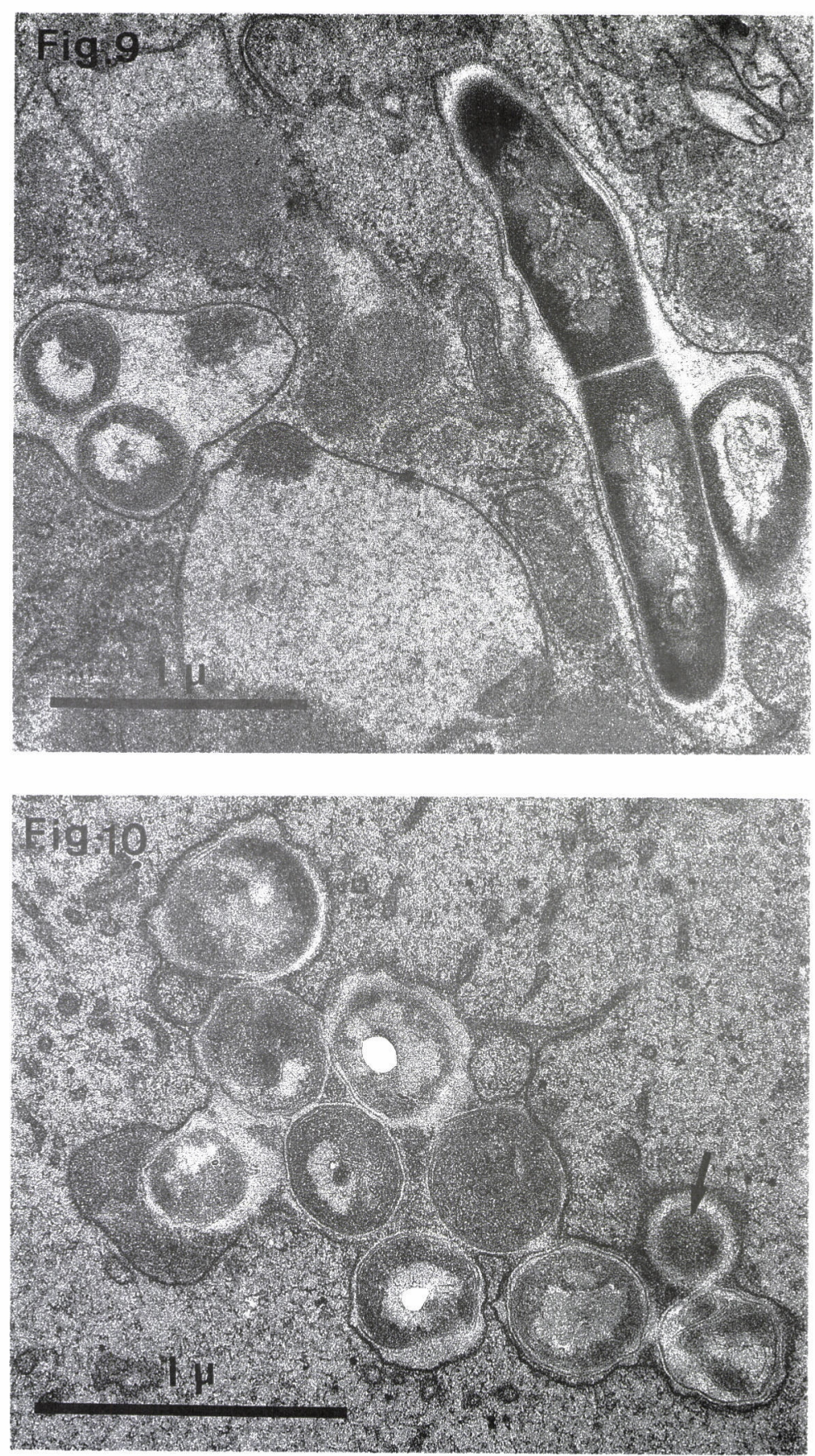

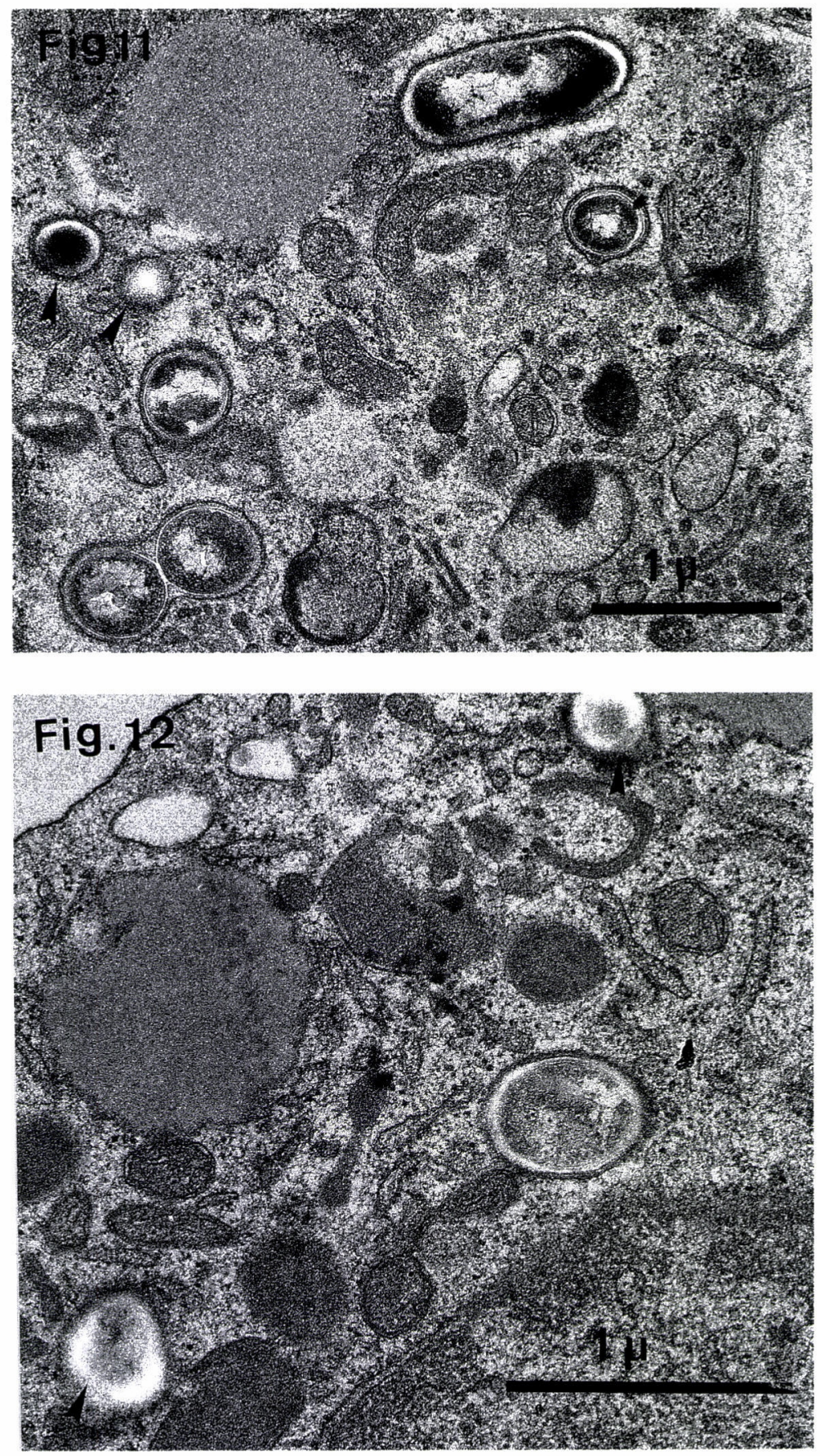